\title{
Building of a community cattle ranch and radio frequency identification (RFID) technology as alternative methods of curtailing cattle rustling in Katsina State
}

\author{
Saifullahi Sani Ibrahim ${ }^{1 *}$, A. Ibrahim², Abdelrasq Na Allah ${ }^{1}$ and Lawal Abdu Saulawa ${ }^{3}$
}

\begin{abstract}
Agriculture is the major component of the rural economy in Katsina State. Livestock production is a major component of agricultural activities practised there and is a source of income and a form of security for farmers. Increasing attacks by cattle rustlers have disrupted the stability that had been enjoyed by pastoralists in rural communities within the State. This study investigates the prospect of adopting community cattle ranches and radio frequency identification (RFID) as strategies for containing cattle rustling. Primary data were sourced via structured questionnaires and dichotomous dependent variable models in the form of probit and logit were used. Siting cattle ranches near rural communities is an important determinant for community acceptance of a cattle ranch, while fees as well as ranch sanitation levels would have significant effects on pastoralist decisions to use group ranch schemes. On the other hand, occupation, number of cattle rustled and education are significant factors in determining the use of RFID. There is growing scepticism over the cruelty in the military approach embarked upon by the current administration in combating cattle rustling, which seems analogous to the intervention used to combat the rise of the Boko Haram insurgency in Nigeria. Therefore, the time is ripe for the government to generate participatory policies whereby consultations should take centre stage in finding solutions to livestock theft. Relevant authorities should urgently build ranches in rural communities, while RFID will be vital to track livestock movement, which will ensure precision for the timely identification of stolen livestock.
\end{abstract}

Keywords: Cattle rustling, Agriculture, Community cattle ranch, Radio frequency identification

\section{Background}

Livestock rearing is one of the major components of agricultural activities performed by more than two thirds of the world's rural populace due to its benefit as a pathway out of poverty (Cornelis et al. 2001; Holmann et al. 2005). Households may sell their livestock and use the proceeds to build or extend their dwellings or acquire capital equipment for farming purposes. Livestock can be perceived as capital assets that provide a form of insurance to poor households that, for various reasons, do not have adequate access to formal financial services (Khoabane and Black 2012). Moreover, evidence shows

\footnotetext{
*Correspondence: ssmatazukt@yahoo.com

'Department of Economics and Development Studies, Faculty of Social

Sciences, Federal University Dutsin-ma, Dutsin-ma, Nigeria

Full list of author information is available at the end of the article
}

that the proceeds from selling livestock are often used to pay for health expenses and school fees of family and relatives. Therefore, livestock implicitly serve as a source of human capital investment in communal settings (Cornelis et al. 2001; Holmann et al. 2005; Khoabane and Black 2012).

Conceptually, the term 'cattle rustling' appears to have evolved into a more or less standardised and specialist nomenclature. The concept is almost universally applied to the act of stealing cattle from a grazing herd, notwithstanding the motivation or contextual specifics. In recent times, the notion of 'cattle raids' was used to denote the same reality (Geiner 2013). Cattle rustling has undergone a fundamental transformation from a cultural practice of testing a person's bravery and prowess to bloody warfare between various groups or communities (Salih 1993). 
Pastoralist contributions to the economies of developing countries, including supporting their own households and supplying animal protein (meat and milk) to villages and towns, are hampered by cattle rustling.

Traditionally, cattle rustling has been driven by criminal intent to expropriate cattle for meat or sale. In the past, rustlers invaded pastoralist communities with arrows and spears, but the practice has now evolved into a pattern of organised crime with immense criminal sophistication, and rustlers have succeeded in building vast networks that cut across different nationalities (Alemika 2013). Cattle theft has been considered to be an unconventional means of primitive accumulation of herds in the contexts of subsistence and commercial pastoralism (Blench 2004). The incidence of stolen cattle is exacerbated by the great importance attached to cattle in some rural communities and has escalated due to deficiencies of traditional forms of identification to aid in tracking and tracing stolen livestock (Okoli and Agada 2014). Cattle raiding is a perennial problem that now disturbs the Nigerian economy. The issue is more alarming in northern rural areas, where cattle rearing is a major occupation, and the problem has been complicated by the rising incidence of farmer-herder conflicts (Chikwuma and Francis 2014). Recently, the wave of cattle rustling in Nigeria has taken the form of massive village raids, whereby herding communities are attacked and stolen items go beyond mere livestock. This pattern of attack has recurred throughout the north-central, north-east and north-west geopolitical zones. However, the incidence is most pronounced in the Bauchi, Plateau, Nasarawa, Benue, Zamfara, Kaduna and Katsina States (Okoli and Okpaleke 2014).

The vast majority of the rural populace in Katsina State primarily engages in agricultural production for subsistence and commercial purposes. Livestock production appears to be second to farming in the ranks of agricultural activities pursued in the State, and the common species of livestock reared include cattle, sheep, goats and poultry (Najamuddeen et al. 2012). In the last decade, the relative normality and stability enjoyed by livestock production in Nigeria was interrupted by a vicious cycle of cattle rustling, which has led to a drastic decline in pastoralist income levels (Kaimba et al. 2011b; Chikwuma and Francis 2014).

Ranching was used in the past as a means of securing livestock in America. However, ranching originated in Spain out of necessity for handling large herds of grazing animals on dry land. There are approximately 3,500 game ranches in South Africa, which are the most modern in Africa, and these networks of ranches have grown from less than 2 million to more than 6 million hectares (Grossman et al. 1992). The success of large-scale cattle ranching in African savanna vegetation is analogous to the success recorded by cowboys in Texas (Tobler et al.
2003). Such large-scale group ranches are not commonly practised in rural communities in Nigeria. The prevailing practice of rural households is to keep their herds near their houses, which poses enormous difficulty for security operatives to counter cattle raids. If, however, a modern ranching practice is adopted, it will be more convenient to provide collective security to livestock in large-scale ranches. Elbakidze (2007) argued that the traceability of animals could be used to prevent the theft or loss of an animal, especially in ranching operations in which cattle owned by several parties are often commingled. The importance of radio frequency identification (RFID) in tracking stolen cattle is well documented in the literature. To our knowledge, no studies are available that have explored these options in Nigeria, despite the severity of cattle theft in pastoralist communities. Therefore, it is imperative to study methods of using large-scale ranches and tracking devices as a means of reducing cattle rustling in Katsina State.

\section{Empirical literature}

There is a significant body of empirical literature on cattle rustling and its impact on socio-economic well-being, particularly in developing countries. In one such study, Richardson and Whitney (1994) surveyed 319 households in Khartoum in an attempt to estimate the factors responsible for household decisions to rear livestock. The study applied a logit model and found that demographic factors, such as education, family size, rural or urban roots and income level, significantly influenced decisions to rear livestock. Similarly, Siegmund-Shultze and Rischkowsky (2001) identified the socio-economic characteristics that influence the decision of households to take up livestock farming in West Africa. In this study, primary data from 130 households were collected through interviews. Logistic regression was employed, and the study revealed that the probability of keeping livestock increases with the size of the household and illiteracy rates.

Cross-border cattle rustling was reported to have a negative effect on the economic fortunes of homesteads in southern Swaziland. At almost all levels, poverty has deepened among rural households because of the adverse effects of raids on agricultural production (Simelane 2005). Along these lines, Holmann et al. (2005) used cross-sectional data from 143 rural dwellers to examine the role of livestock production on poverty alleviation in Colombia. The study found that cattle ownership by household serves as a pathway out of poverty, while cattle owners mainly sold their cattle when the probability of rustling was high. Similarly, Thys et al. (2005), in an examination of the socio-economic determinants of urban livestock production in a semi-arid environment, documented that theft (cattle rustling), animal health problems, feed supply and manure management constrain livestock farming. 
The impact of cattle theft on household migration decisions in Baringo District of Kenya was investigated by Kaimba et al. (2011a). Interviews with 110 used a structured questionnaire, and the binary probit model was used to explain the probability of pastoralist migration from volatile areas to safer areas, while ordinary least squares (OLS) was used to explain its effects on herd size. The study found that the gender and age of the head of household were significant determinants of migration and significantly influenced herd size. Moreover, the intensity of cattle rustling and loss of livestock to drought and or disease also significantly influenced decisions to migrate from one place to another. Manu et al. (2014) examined the socio-economic effects of cattle theft on pastoralism in the north-west region of Cameroon. They documented that cattle rustling has often led to a reduction in the income levels of livestock producers and, by extension, adversely affects the socioeconomic well-being of residents in affected areas.

The traceability of livestock could not only be used in the prevention of cattle theft but could also be helpful in tracking the movement of displaced livestock. There is a growing body of literature advocating the potential gains of using various types of livestock tracking systems (LTS) for tracing lost or stolen livestock. On the other hand, other studies centre on the use of LTS for livestock tracing for health reasons. Among all LTS, RFID is often considered to be the most widely adopted method over other competing alternatives, due to RFID's relatively low cost compared to benefits (Suh et al. 2013). Pongpaibool (2008) suggested the use of a high-frequency RFID tag as a solution for the quick tracking and tracing of livestock. Ekuam (2009) argued that livestock identification via RFID is essential for human security by ensuring the precise tracking of livestock movement, which would enable timely responses to raids. Along these lines, Siror et al. (2009) contended that RFID technologies can be used to combat incessant cattle rustling in Eastern Africa, and Jinaporn et al. (2008) stressed the need for RFID as a robust security system against asset theft.

The instant monitoring of movement and tracking of livestock by LTS is essential in maintaining stable health conditions and feeding patterns in animals. Traceability would allow for tracking and identifying potentially unhealthy livestock, thereby enhancing control efficiency as well as fasttracking livestock disease eradication mechanisms (Elbakidze 2007). Thurner et al. (2011) examined the management of young cattle on alpine pastures using a global positioning system (GPS)-based livestock tracking device on 36 cattle. Their results confirmed the statistical accuracy of LTS between 7.5 and 11.2 median deviations from the initial position. The most striking aspect of this study is the postulation that positioning the LTS on the neck gave robust precision to the median number of records received from the animal. Porto et al. (2013) invented a vision-based system for the automatic detection of the lying behaviour of dairy cows in free-stall barns and found a $92 \%$ precision of RFID detection of various cow lying behaviours. An automatic livestock tracking programme can be a solution to trace livestock welfare problems (Huhtala et al. 2007). Maselyne et al. (2014) maintained that the regular monitoring of feeding habits of livestock through RFID would enable the early detection of diseases and other related problems.

\section{Theoretical framework}

This study benefitted immensely from the enterprise theory of organised crime. Under this theory, organised crime exists because legitimate markets leave many customers and potential customers unsatisfied (Smith 1978). The impetus behind organised crime is not a criminal conspiracy, but simple market opportunity, which can also constrain organised crime's structure, form and social perniciousness. Therefore, the market and its environment provide the most appropriate point of intervention in controlling organised crime (Lyman and Potter 2007). Once there is demand for cattle due to the importance of beef to farmers and consumers alike, then the number of cattle raids would escalate. Assuming an ever-increasing market demand for illegally acquired goods due to lower prices, Liddick (1999) rightly observed that as long as demand exists, a marketplace exists, and entrepreneurs (cattle rustlers in the case of this study) will seek to meet demand regardless of the legality of the transaction. Reuter (1983) believed that several factors have direct consequences for entrepreneurs conducting business in illegal markets. The principal factor could be the need to restrict knowledge to prospective enterprise entrants due to the monopolistic tendencies of entrepreneurs. This would enable them to appropriate all of the available profit of the illegal market. The lack of an external credit market and the lack of contracts backed by the weight of law provide the justification for profitable criminality in a country (Albanese 2000).

In a society in which organised crime is rampant, law enforcement agencies should, as a matter of urgency, disrupt the organisational environment by apprehending the perpetrators. Otherwise, criminal enterprise will expand beyond control, noting that crime is profitable because of strong public demand for the goods and services supplied at rates far below competitive market prices (Smith 1980). It is obvious that a long-term plan is required to combat organised crime such as cattle rustling. However, short-term coping measures in the form of building community cattle ranches and RFID are pertinent.

\section{Study area}

Katsina State is located on the high plains of Hausaland approximately $733 \mathrm{~m}$ above sea level. The coordinates of the State are latitudes $11^{\circ} 30^{\prime} \mathrm{N}-13^{\circ} 15^{\prime}$ north and longitudes 
$6^{\circ} 52^{\prime} \mathrm{E}-09^{\circ} 20^{\prime}$ east. The State is composed of 34 local government areas (LGAs), divided into 3 senatorial zones, namely, Katsina Central, Katsina South and Katsina North. Farming is the predominant economic activity, particularly in rural areas. Cattle theft mainly occurs in six LGAs that cut across Katsina Central and South axes. The affected LGAs are Sabuwa, Danmusa, Safana, Batsari, Faskari and Kankara. Coincidentally, these LGAs share borders with some States within the north-west geopolitical zone that are simultaneously hit by incessant cattle theft. For instance, Faskari, Danmusa, Batsari, Safana, Kankara and Sabuwa border Zamfara State and Kaduna State. Moreover, other parts of the State are bounded to the north by the Niger Republic and to the east by Kano and Jigawa States (see Figure 1). The State covers an area of 23,938 $\mathrm{km}^{2}$, which accounts for approximately $2.7 \%$ of the total land area of Nigeria.

\section{Materials and methods}

Surveys in the affected communities were conducted between July and September 2015, and five communities were randomly selected from each of the previously mentioned LGAs. The sample size of 1,750 was distributed proportionately to the total number of inhabitants in each of the selected communities. Structured questionnaires were administered to randomly selected respondents. Approximately $85 \%$ of the questionnaires administered were determined to be analysable. Unfortunately, pastoralists in the study area are accustomed to the traditional method of keeping livestock in portions set aside for herds within their houses. The dearth of large-scale group ranches within the communities surveyed suggested the idea of fabricating virtual ranches for demonstration purposes. This afforded livestock producers with an image of the ranches and familiarised them with their use in providing a comprehensive security package for livestock.

\section{Empirical model}

Classical OLS is inefficient in estimating system equations with dependent variables that exhibit a dichotomous response. In such a scenario, OLS cannot effectively produce the best linear unbiased estimation. Fortunately, both the probit and logit models are not only the most popular statistical methods developed to analyse dichotomous responses of dependent variables in regression models but also yield more efficient and consistence parameter estimations (Demaris 1992; Long 1997). The choice of the logit model to estimate the factors that determine the acceptance of RFID over the probit model is based on Peng et al. (2002), who suggested that logit is well suited for explaining and testing hypotheses about relationships between categorical outcome variables and one or more categorical or continuous variables.

Decisions of pastoralists to use community cattle ranches and adopt RFID depend on the vectors of regressors:

$$
y_{i}^{*}=\chi_{0}+\sum_{n=1}^{N} \chi_{n} x_{i n}+\mu_{i}
$$

The equation can be expressed as

$$
y_{i}^{*}=\chi_{0}+\chi_{1} x_{i 1}+\chi_{2} x_{i 2}+\chi_{i} x_{i 3}+\ldots+\chi_{k} x_{i k}+\mu_{i}
$$

and that

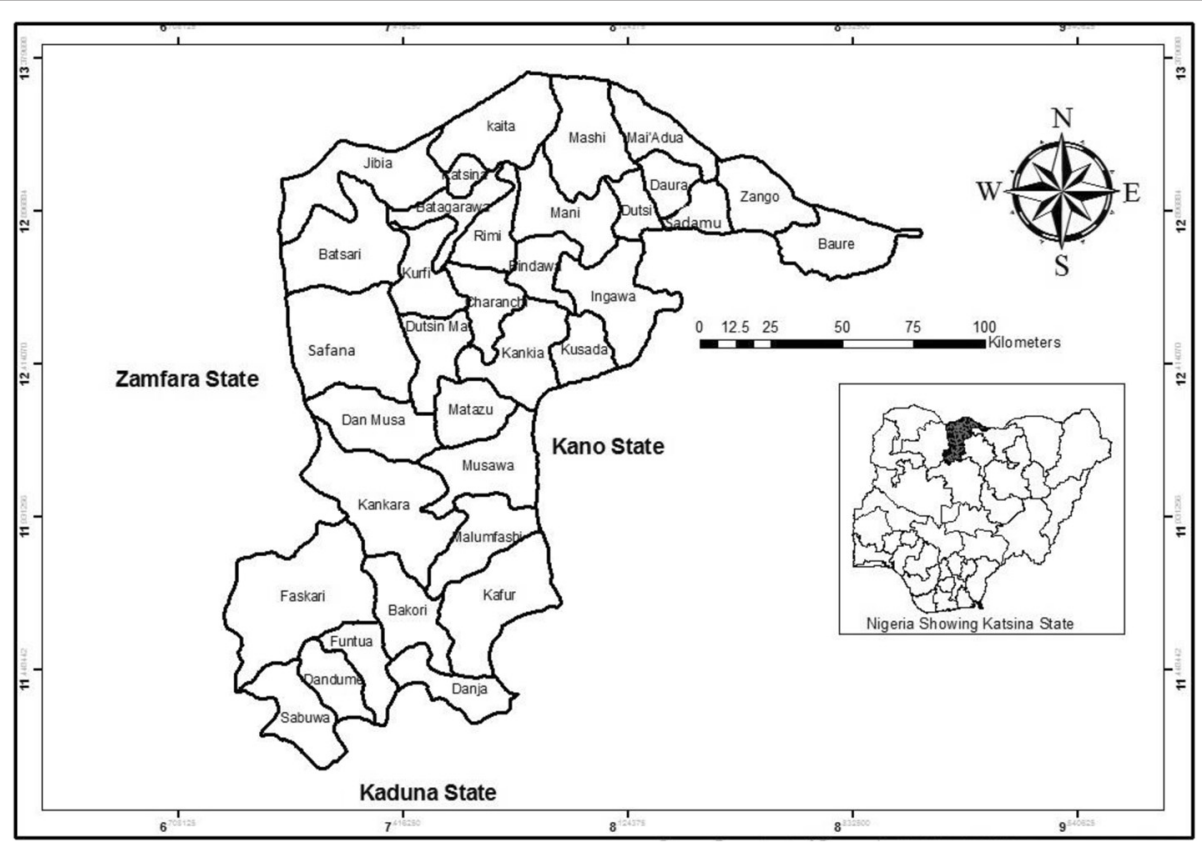

Figure 1 Administrative map of Katsina State showing the LGAs 


$$
y_{i}^{*}=1_{1 \text { if } y=0} \text { and } 0_{\text {if otherwise }}
$$

where $y$ is a latent unobserved variable whose outcome is observed at 1 and 0 and $x_{i}$ is the vector of the independent variable in the models.

\section{Model specification}

Pastoralist decisions to use community cattle ranches are determined by a host of independent variables and are thus modelled below:

$$
\begin{aligned}
\operatorname{ccr}_{i}^{*}=\sum_{i=1}^{1,487} \beta_{k} & + \text { acaranch }_{i}+\text { security }_{i}+\text { proximity }_{i} \\
& + \text { sanita }_{i}+\text { fees }_{i}+\varepsilon_{1}
\end{aligned}
$$

where

ccr

Community cattle ranch $(1=$ if the respondent indicated a willingness to use a cattle ranch if provided, $0=$ otherwise) acaranch

Availability of a cattle ranch in the community security

Level of security of the cattle ranch proximity

Distance between the cattle ranch and town sanita

Sanitation or cleanness in the cattle ranch fees

Fees for keeping cattle

$\varepsilon_{i}$

White noise error term

The prospects of using community cattle ranches depend on the availability in the rural community $(+)$, level of security $(+)$, distance between the ranching site and town $(-)$, sanitation $(+)$ and fees charged for keeping cattle (-).

The logit model that captures the prospect of using RFID as a tracking device is given below:

$$
\begin{aligned}
\text { RFID }=\varphi_{0} & +\lambda_{1} \text { age }+\lambda_{2} \text { gender }+\lambda_{3} \text { marista } \\
& +\lambda_{4} \text { nocatrust }+\lambda_{5} \text { edu }+\lambda_{6} \text { nolivfam }+\mu_{i}
\end{aligned}
$$

where

RFID

Radio frequency identification $(1=$ accepted, $0=$ otherwise)

age

Respondent's age

gender

Gender

marista

Marital status

nocatrust

Number of cattle stolen edu

Level of education

nolivfam

Number of livestock farmers

$\mu_{i}$

White noise error term

These variables are a priori expected to exhibit a posi-

\begin{tabular}{|c|c|c|c|}
\hline $\begin{array}{l}\text { Local Government } \\
\text { Area (LGA) }\end{array}$ & $\begin{array}{l}\text { Frequency of } \\
\text { households }\end{array}$ & Percent & $\begin{array}{l}\text { Households affected } \\
\text { by cattle rustling }\end{array}$ \\
\hline Batsari & 319 & 21 & $170(53 \%)$ \\
\hline Danmusa & 241 & 16 & 198 (82 \%) \\
\hline Faskari & 242 & 16 & 77 (32 \%) \\
\hline Kankara & 186 & 13 & $64(34 \%)$ \\
\hline Sabuwa & 252 & 17 & 231 (92 \%) \\
\hline Safana & 254 & 17 & $164(65 \%)$ \\
\hline \multicolumn{4}{|l|}{ Gender } \\
\hline Male & 1,384 & 93 & 836 (63 \%) \\
\hline Female & 104 & 7 & $67(67 \%)$ \\
\hline \multicolumn{4}{|l|}{ Age } \\
\hline 18 and below & 103 & 7 & $48(5 \%)$ \\
\hline 19 to 45 & 916 & 62 & 545 (61 \%) \\
\hline 46 to 60 & 377 & 25 & $251(28 \%)$ \\
\hline Above 60 & 85 & 6 & $53(6 \%)$ \\
\hline \multicolumn{4}{|l|}{ Marital status } \\
\hline Single & 156 & 10 & 70 (9 \%) \\
\hline Married & 1,269 & 85 & 786 (88 \%) \\
\hline Divorced & 27 & 2 & $20(2 \%)$ \\
\hline Separated & 5 & 0.33 & $5(0.5 \%)$ \\
\hline Widow & 17 & 1 & $11(1 \%)$ \\
\hline \multicolumn{4}{|l|}{ Education } \\
\hline Primary & 170 & 11 & 97 (11\%) \\
\hline Secondary & 249 & 17 & $108(12 \%)$ \\
\hline $\begin{array}{l}\text { Diploma and } \\
\text { equivalent }\end{array}$ & 181 & 12 & 81 (9 \%) \\
\hline Graduate & 48 & 3 & 16 (2\%) \\
\hline Qur'anic education & 832 & 56 & 597 (66 \%) \\
\hline \multicolumn{4}{|l|}{ Occupation } \\
\hline Agriculture & 664 & 45 & $543(67 \%)$ \\
\hline Civil servant & 111 & 8 & $23(50 \%)$ \\
\hline Businessmen & 421 & 28 & $74(47 \%)$ \\
\hline Politicians & 80 & 5 & $55(80 \%)$ \\
\hline Traditional rulers & 116 & 8 & $90(78 \%)$ \\
\hline Security agents & 94 & 6 & $52(55 \%)$ \\
\hline
\end{tabular}
tive prospect in the decision to use RFID by pastoralists in rural communities.

Table 1 Descriptive responses from the survey

Source: Survey, 2015 


\section{Empirical results}

Descriptive responses from the survey are presented in Table 1 and suggest that $92 \%$ of the respondents in the Sabuwa local government area have been affected by cattle rustling. This is higher than the $82 \%, 65 \%$ and $53 \%$ of respondents for Danmusa, Safana and Batsari, respectively. Moreover, Faskari (32 \%) and Kankara (34 \%) also had fewer victims of cattle theft. The demographic distribution of respondents shows that males constituted an overwhelming majority, $93 \%$, while only $7 \%$ were females. The distribution of the burden of cattle theft is not equal among genders, with $67 \%$ females having their cattle stolen. Of 1,384 males surveyed, $63 \%$ were victims of cattle raids. It is worth noting that cattle rustling more frequently affected younger individuals between the ages of 19 and 45 (62\% of individuals in this age category have had their livestock rustled). The vast majority $(85 \%)$ of respondents were married, $88 \%$ of whom have had their cattle stolen. The results also reveal that $56 \%$ of the respondents attended an Islamic school and acquired Qur'anic education. The preponderance of respondents did not receive a Western education, and $11 \%, 17 \%, 12 \%$ and $3 \%$ possessed primary, secondary, diploma and graduate-level certificates, respectively.

The distribution of cattle theft burden is not equal among the various categories of respondents. Traditional farmers have suffered more from cattle theft than the other groups. A total of 664 respondents were farmers, of whom $67 \%$ had their cattle stolen, and 421 were businessmen/women, with $47 \%$ of them having fallen victim to cattle rustling. Approximately $78 \%$ of the traditional rulers have had their livestock stolen, while of the 94 security agents, only $55 \%$ had lost livestock through theft.

\section{Decision to keep cattle in community cattle ranches}

Pastoralist decisions to keep cattle in ranches would, to a large extent, depend on the level of security available at the ranching site. Similarly, large-scale group ranches need to be sited near rural communities, as the proximity of ranches is an important factor to consider in the decision to keep livestock. In the same vein, the sanitation levels would exert considerable influence in decisions to use a cattle ranch. A considerable $36 \%$ and $35 \%$ of pastoralists indicated that the sanitation levels in ranches would very greatly and greatly impact their decision to keep cattle in large-scale group ranches, respectively (see Figure 2).

Moreover, approximately $60 \%$ respondents indicated that the level of security of the cattle ranch would very greatly influence their decision to use public ranches, while $36 \%$ believe that community cattle ranches should be sited very close to their town as opposed to being located at distant places. Imposing any fee for the usage of public ranches would not necessarily deter livestock producers from using community cattle ranches. Given the acceptance of a fee for group ranches by pastoralists, ranches could represent a new revenue base for public authorities, which is very important during this period of dwindling crude oil prices.

It is apparent from the probit regression in Table 2 that the nearness (proximity) of the ranching site, fees and level of sanitation in the cattle ranches would have significant effects on the decision to use group ranches. The model specified in Equation (5) passed the goodness-of-fit tests as shown by a significant likelihood ratio (LR) chi-square test value of 59.27 (0.0000). In other words, the model exhibited good predictive power in explaining the relationship between the regressors and the regressand. It can be seen from the results that, provided that the factors that exert varying degrees of influence on the decision to keep livestock in ranches are taken into account, community cattle ranches would probably be accepted in rural areas in Katsina State. Given the growing cattle raids in the state, Table 3 reveals the readiness of pastoralists to use these methods when provided by the government.

Factors affecting decision to keep cattle in community cattle ranch

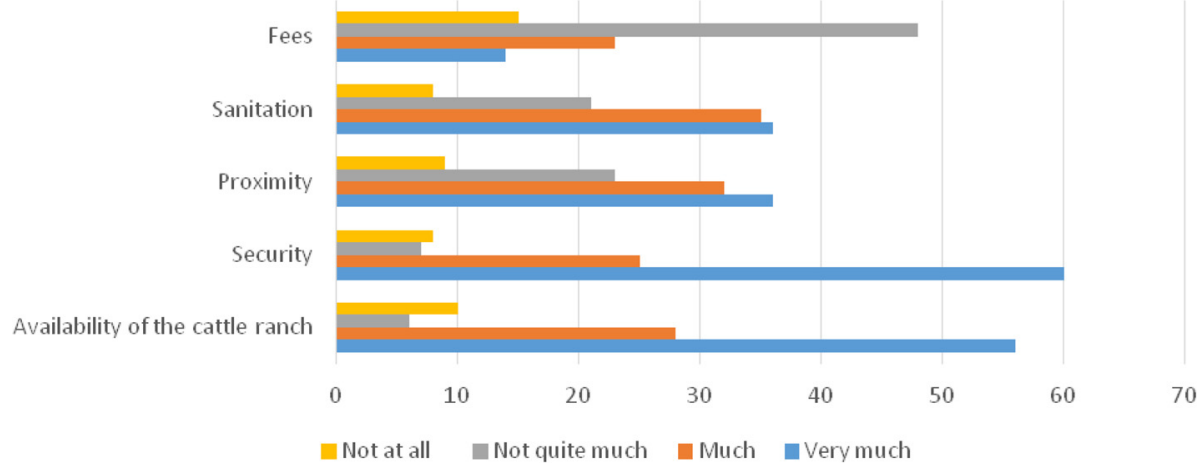

Figure 2 Factors affecting decision to keep cattle in community cattle ranch 
Table 2 Probit regression

\begin{tabular}{lll}
\hline Variables & Coefficient & $P$ value \\
\hline Availability of cattle ranch & -0.94 & 0.451 \\
Security & 0.196 & 0.187 \\
Proximity & $0.624^{* * *}$ & 0.000 \\
Sanitation & $-1.127^{* * *}$ & 0.000 \\
Fees & $0.560^{* * *}$ & 0.000 \\
$N$ & 1,487 & \\
Pseudo $R^{2}$ & 0.093 & \\
LR chi ${ }^{2}$ (5) & $59.27(0.0000)$ & \\
Log likelihood & -290.514 & \\
\hline
\end{tabular}

*** denotes significant at $1 \%$

Large-scale public ranching operations involve combining the ownership of livestock by several pastoralists into one common ranch. There is a tendency for identification challenges due to inadequate forms of identification to provide high ultra-precision identification of large numbers of livestock. This would further necessitate the use of modern tracking devices in public ranching services.

\section{Determinants of the acceptability of RFID}

A lack of tracking devices is one of the reasons for escalating cattle theft in rural communities. Table 4 shows the logit results of the factors that determine the likelihood of using RFID as a tracking device by pastoralists in Katsina State. The results show that certain social characteristics of the respondents, such as age, gender and marital status, were not statistically significant. However, their respective signs have an interesting economic The signs portrayed by the estimated parameters are the same as those for RFID, meaning that modern tracking devices have positive prospects in

Table 3 Prospect of a community cattle ranch and RFID. Response to questions put to respondents to assess their readiness to adopt group ranching scheme and RFID

\begin{tabular}{|c|c|c|}
\hline & Frequency & Percent \\
\hline \multicolumn{3}{|c|}{ Community cattle ranch in rural areas } \\
\hline Yes & 648 & 43 \\
\hline No & 742 & 50 \\
\hline \multicolumn{3}{|c|}{ Acceptability of community cattle ranch } \\
\hline Accepted & 1,095 & 73 \\
\hline Rejected & 308 & 21 \\
\hline \multicolumn{3}{|c|}{ Acceptability of RFID } \\
\hline Accepted & 916 & 61 \\
\hline Rejected & 305 & 21 \\
\hline
\end{tabular}

Source: Survey, 2015
Table 4 Logistic regression

\begin{tabular}{lll}
\hline Variables & Coefficient & z-ratio \\
\hline Age & 0.134 & 0.13 \\
Gender & 0.440 & 1.54 \\
Marital status & 0.201 & 1.56 \\
Occupation & $0.110^{* * *}$ & 2.73 \\
Number of cattle rustled & $0.251^{* * *}$ & 4.37 \\
Education & $0.167^{* * *}$ & 3.74 \\
Livestock farming & -0.077 & -0.44 \\
$N$ & 1,487 & \\
Pseudo $R^{2}$ & 0.050 & \\
LR chi ${ }^{2}$ (8) & $70.85(0.0000)$ & \\
Log likelihood & -290.514 & \\
\hline
\end{tabular}

*** denotes significant at $1 \%$

This reported the result of factors that influence the adoption of RFID by pastoralists. Number of cattle rustled is expected to capture how cattle raid has depleted the herd-size. Literacy level is vital in making decision to use RFID. Respondent occupation, as to whether livestock is the sole occupation or not. Some socio-economic factors like age, gender marital status were added in the model. The results indicated that Occupation, herd-size and education level were the significant factors

pastoralist communities. Literacy, which is loosely measured by education level, is a very important variable (significant at the $1 \%$ level of significance) in decisions to use modern tracking devices. Log likelihood ratio statistics $\left(\mathrm{LR} \mathrm{chi}^{2}(8)=70.85\right)$ indicate that the model fits the data very well and is significant at the $1 \%$ level. RFID as a modern livestock identification and tracking technique appears to have potentially positive prospects in Katsina State. These results corroborate with the descriptive results in Table 4, which shows that $62 \%$ of the respondents registered their admiration for the device in tracking livestock movements.

\section{Conclusion}

This study explored the prospect of large-scale group cattle ranches and RFID as strategies for combating cattle rustling in Katsina State. The study used primary data obtained via survey in rural communities in the State, and applied categorical dependent variable models in the form of logit and probit models. The results reveal that siting cattle ranches close to rural communities is an important determinant for the use of community cattle ranching and that fees and sanitation levels have significant effects on the decision to keep cattle in ranches. On the other hand, occupation, number of cattle rustled and educational attainment are significant factors in making the decision to use RFID. This study has identified that the magnitude of cattle rustling is severe and often seriously affects agricultural production, thereby eroding the income of pastoralists and farmers alike. Military intervention embarked upon by the current administration has yet to yield fruitful results. Growing scepticism of the current counter cattle 
raids rests on the fear that the approach is very similar to the one that led to the emergence of Boko Haram in the north-eastern geopolitical zone. Therefore, the time is ripe for the government to enact participatory policies in which adequate consultation should take centre stage in finding lasting solutions to livestock theft. Relevant authorities should urgently build community cattle ranches in rural communities, while RFID will be vital for tracking livestock movement and will offer precision in the identification of stolen livestock and timely responses.

\section{Competing interests}

The authors declare that they have no competing interests.

\section{Authors' contributions}

SSI contributed in the conception, design, data collection, analysis and drafted the manuscript. Al contributed qustionnaire design, conducted pilot, participated in data collection, provided information about study area and proof read the manscript. LAS and ANA provided technical guidance in the conception and the structure of manuscripts. All authors read and approved the final manuscript.

\section{Acknowledgements}

We wish to thank an anonymous referee for the useful comments on a previous version of the manuscript. Similar thanks go to the Editor-in-Chief for the relevant suggestions, which have helped in improving the quality of the paper. We are grateful to the Tertiary Education Trust Fund (Tetfund) for the research grant awarded to us through a Federal University Dutsin-ma (FUDMA) Institutional Grant.

\section{Author details \\ ${ }^{1}$ Department of Economics and Development Studies, Faculty of Social Sciences, Federal University Dutsin-ma, Dutsin-ma, Nigeria. ${ }^{2}$ Department of Geography and Regional Planning, Faculty of Social Sciences, Federal University Dutsin-ma, Dutsin-ma, Nigeria. ${ }^{3}$ Department of Animal Production and Health, Faculty of Agriculture, Federal University Dutsin-ma, Dutsin-ma, Nigeria.}

\section{Received: 29 October 2015 Accepted: 13 April 2016}

\section{Published online: 03 June 2016}

\section{References}

Albanese, J. 2000. The causes of organized crime: Do criminals organize around opportunities for crime or do criminal opportunities create new offenders? Journal of Contemporary Criminal Justice 16(4): 409-423.

Alemika, E.E. 2013. The impact of organised crime on governance in West Africa. Abuja: Friedrich-Ebert-Stiftung.

Blench, R. 2004. Natural resource conflicts in north-central Nigeria. A handbook and case studies. London: Mandaras publishing.

Chikwuma, O.A., and N.O. Francis. 2014. Cattle rustling and dialectics of security in Northern Nigeria. International Journal of Liberal Arts and Social Science 2(3): 109-117.

Cornelis, H., T.S. Van Veen, B. Brandenburg, J. Gauthier, F. Le Gall, R. Mearns, and M. Simeon. 2001. Livestock development: Implications for rural poverty, the environment and global food security, directions and development. Washington, D.C.: The World Bank.

Demaris, A. 1992. Logit modelling: Practical applications. Newbury Park, CA: Sage.

Ekuam, D.E. 2009. Livestock identification, traceability and tracking: Its role in enhancing human security, disease control and livestock marketing in InterGovernmental Authority on Development (IGAD) region. Rome: Food and Agricultural Organisation. http://www.fao.org/fileadmin/user_upload/ drought/docs/livestock\%20ID.pdf.

Elbakidze, L. 2007. Economic benefits of animal tracing in the cattle production sector. Journal of Agricultural and Resource Economics 32(1): 169-180.

Geiner, C. 2013. Guns, land, and votes: Cattle rustling and the politics of boundary (re)making in Northern Kenya. African Affairs 112(447): 216-237. http://afraf.oxfordjournals.org/content/112/447/216.full.pdf \pm html. (Accessed 6 Oct 2015).
Grossman, D., T.A. Ferrar, and P.C. du Plessis. 1992. Socioeconomic factors influencing conservation in South Africa. Traffic Bull 13: 20-31.

Holmann, F., L. Rivas, N. Urbina, B. Rivera, A.L. Giraldo, S. Guzman, M. Martinez, A. Medina, and G. Ramirez. 2005. The role of livestock in poverty alleviation: An analysis of Colombia. Livestock Research for Rural Development 17(1): 1-15. http://www.lrrd.org/lrrd17/1/holm17011.htm. (Accessed 9 Jul 2015). (Accessed 9 July 2015).

Huhtala, A., K. Suhonen, P. Makela, M. Hakojarni, and J. Ahokas. 2007. Evaluation of instrumentation for cow positioning and tracking indoors. Biosystems Engineering 96(3): 399-405.

Jinaporn, N., S. Wisadsud, P. Nakonrat, and A. Suriya. 2008. Security system against asset theft by using Radio Frequency Identification Technology. Proceeding of $5^{\text {th }}$ International joint conference on Electrical Engineering/Electronics, Computer, Telecommunications and Information Technology, 761-764.

Kaimba, G.K., K.B. Njehia, and A. Guliye. 2011a. Effects of cattle rustling and household characteristics on migration decisions and herd size amongst pastoralists in Baringo District in Kenya. Pastoralism: Research Policy and Practice 1(18): 1-16. http://www.pastoralismjournal.com/content/1/1/18. (Accessed 6 Oct 2015).

Kaimba, G.K., G.A. Yakuba, N.B. Kamau, and H.K. Bett. 2011 b. Livestock marketing decisions among pastoral communities: The influence of cattle rustling in Baringo District, Kenya. International Journal of Agricultural management \& Development 1(3): 123-137.

Khoabane, S., and P. Black. 2012. On the economic effect of livestock theft in Lesotho: An asset-based approach. Journal of Development and Agricultural Economics 4(5): 142-146.

Liddick, D. 1999. The enterprise model of organized crime: Assessing theoretical propositions. Justice Quarterly 16(2): 403-430. http://dx.doi.org/10.1080/ 07418829900094191. (Accessed 3 Oct 2015).

Long, J.S. 1997. Regression models for categorical and limited dependent variables. Thousand Oaks, CA: Sage.

Lyman, MD and GW Potter. 2007. Organized Crime, 4th ed., Upper Saddle River, NJ: Pearson Prentice Hall. 59-83.

Manu, I.N., W.N. Andu, D.N. Tarla, and W.N. Agharih. 2014. Socio-economic effect of cattle theft on the pastoralists of the North-west Region of Cameroon. Scholarly Journal of Agricultural Science 4(6): 299-305. Retrieved on 2nd October 2015. http://www.scholarlyjournals.com/sjas/archive/2014/April/pdf/ Manu\%20et\%20al.pdf.

Maselyne, J., A. Van Nuffel, B. De Ketelaere, J. Vangeyte, E.F. Hessel, B. Sonck, and W. Saeys. 2014. Range measurements of High Frequency Radio Frequency Identification (HF RFID) system for registering feeding patterns of growingfinishing pigs. Computers and Electronics in Agriculture 108: 209-220.

Najamuddeen, G., M.B. Sayaya, A.L. Ala, and M.G. Garba. 2012. Economics of potatoes production in Katsina Metropolis, Katsina state, Nigeria. Scientific Journal of Crop Production 1(3): 48-54

Okoli, A.C., and A.T. Agada. 2014. Kidnapping and national security in Nigeria. Research on Humanities and Social science 4(6): 137-146.

Okoli, A.C., and F. Okpaleke. 2014. Banditry and crisis of public safety in Nigeria: Issues in national security strategies. European Scientific Journal 10(4): 350-362.

Peng, C.J., K.L. Lee, and G.M. Ingerson. 2002. An introduction to logistic regression analysis and reporting. Journal of Educational Research 96(1): 1-14.

Pongpaibool, P. 2008. A study on performance of UHF RFID tags in a package for animal traceability application. Proceedings of $5^{\text {th }}$ International joint conference on Electrical Engineering/Electronics, Computer, Telecommunications and Information Technology, 741-744.

Porto, S.M.C., C. Arcidiacomo, U. Anguzza, and G. Cascone. 2013. A computer vision-based system for the automatic detection of lying behaviour of dairy cows in free-stall barns. Biosystems Engineering 115: 184-194.

Reuter, P. 1983. Disorganised crime: The economics of the visible hand. Cambridge, MA: MIT Press.

Richardson, M.G., and B.R. Whitney. 1994. Goats and garbage in Khartoum, Sudan: A study of the urban ecology of animal keeping. Human Ecology 23(4): 455-475.

Salih, M.A. 1993. Agro-pastoralism: An underestimated regional food production system. Eastern Africa Social Science Review 9(1): 23-37.

Siegmund-Shultze, M., and B. Rischkowsky. 2001. Relating households characteristics to urban sheep keeping in West Africa. Agricultural Systems 67(2001): 139-152.

Simelane, H.S. 2005. Cross-border cattle rustling and its socioeconomic impact on rural Southern Swaziland, 1990-2004. Journal of Contemporary African Studies 23(2): 215-231. http://dx.doi.org/10.1080/ 02589000500176107 
Siror, J.K., S. Huanye, D. Wang, and W. Jie. 2009. Use of RFID technologies to combat cattle rustling in the East Africa. In J. Kim, D. Delen, P. Jinsoo, F. Ko, C. Rui, J.H. Lee, W. Jian and G. Kou, (Eds). Proceedings of joint conferences on network competing; advanced information management and services; and digital content, multimedia technology and its application. Los Alamitos: institute of electrical and electronics engineers.

Smith, D.C. 1978. Organized crime and entrepreneurship. International Journal of Criminology and Penology 6(2): 161-177.

Smith, D.C. 1980. Paragons, pariahs, and pirates: A spectrum-based theory of enterprises. Crime and Delinquency 26(3): 358-386.

Suh, W.S., E.J. Yoon, and S. Piramuthu. 2013. RFID-based attach scenarios in retailing, healthcare and sports. Journal of Information Privacy and Security 9(3): 4-17.

Thurner, S., G. Neumaier, and G. Wendl. 2011. Management of young cattle on alpine pastures using a GPS-based livestock tracking system. In Grassland farming and land management systems in mountainous regions. Proceedings of the 16th symposium of the European Grassland Federation. Gumpenstein, Austria, 29th - 31st August, ed. E. Postsch, M. Krautzer, and A. Hopkins, 103-105.

Thys, E., M. Oueadraogo, N. Speybroeck, and S. Geerts. 2005. Socioeconomic determinants of urban household livestock keeping in semi-arid Western Africa. Africa Journal of Arid Environments 63: 475-496.

Tobler, M.W., R. Cochard, and P.J. Edwards. 2003. The impact of cattle ranching on large-scale vegetation patterns in a coastal savanna in Tanzania. Journal of Applied Ecology 40: 430-444.

\section{Submit your manuscript to a SpringerOpen ${ }^{\circ}$ journal and benefit from:}

- Convenient online submission

- Rigorous peer review

- Immediate publication on acceptance

- Open access: articles freely available online

- High visibility within the field

- Retaining the copyright to your article

Submit your next manuscript at $\gg$ springeropen.com 